\title{
MENUMBUHKAN KEMAMPUAN \\ BERPIKIR KRITIS SISWA DALAM \\ MEMILIH MAKANAN SEHAT DENGAN PEMBELAJARAN LITERASI MATEMATIKA BERBASIS KONTEKS
}

\author{
Ahmad Anis Abdullah ${ }^{1}$, Rino Richardo ${ }^{2}$ \\ 1'Anis02108882@gmail.com, ${ }^{2}$ rinorichardo@almaata.ac.id \\ 1,2Prodi Pendidikan Matematika \\ Universitas Alma Ata Yogyakarta \\ 2017
}

\begin{abstract}
Abstrak
Penelitian ini bertujuan untuk mendeskripsikan bagaimana mengembangkan kemampuan berpikir kritis siswa dalam memilih makanan sehat dengan pembelajaran literasi matematika berbasis konteks. Metode yang digunakan dalam penelitian ini merupakan penelitian studi kepustakaan (library research). Literasi matematika merupakan kemampuan menggunakan pengetahuan matematika guna memecahkan masalah sehari-hari secara lebih baik dan efektif. Literasi matematika dapat membantu individu untuk mengenal peran matematika di dunia nyata dan sebagai dasar pertimbangan dalam penentukan keputusan yang dibutuhkan oleh masyaraka, seperti berpikir kritis dalam memilih makanan sehat. Hasil penelitian ini menunjukkan bahwa pemilihan makanan sehat khususnya makanan kemasan dengan pembelajaran literasi matematika berbasis konteks, dapat dilakukan pada pembelajaran tematik di sekolah dasar, sub pokok pembahasan perbandingan dengan objek penelitian tanggal kadaluarsa dan informasi nilai gizi dalam produk kemasan.
\end{abstract}

Kata kunci: literasi statistika, pembelajaran matematika, pendidikan politik, berpikir kritis

\begin{abstract}
This study aims to describe how to develop students' critical thinking skills in choosing healthy food with context-based mathematics literacy learning. The method used in this study is a literature study. Mathematical literacy is the ability to use mathematical knowledge to solve daily problems better and more effectively. Mathematical literacy can help individuals to recognize the role of mathematics in the real world and as a basis of consideration in the decision-making needed by society, such as critical thinking in choosing healthy foods. The results of this study indicate that the selection of healthy foods, especially food packaging with context-based mathematics literacy learning, can be done on thematic learning in primary schools, sub-subject discussion of comparison with the object of discussion is expired date and nutritional value information in packaging products.
\end{abstract}

Keywords: healthy food, critical thinking, mathematics learning, Mathematical literacy 


\section{JURNAL GANTANG. September 2017; II(2): 89 - 97 \\ p-ISSN. 2503-0671 \\ e-ISSN. 2548-5547}

\section{Pendahuluan}

Peraturan perundang - undangan menetapkan bahwa semua makanan yang dikemas harus mempunyai label yang memuat keterangan tentang isi, jenis, dan jumlah bahanbahan yang digunakan, tanggal kadaluarsa, komposisi zat gizi yang dinyatakan dalam jumlah dan sebagai persen Angka Kecukupan Gizi yang Dianjurkan (AKG) untuk tiap takaran saji, serta keterangan penting lainnya (seperti kehalalan produk). Dengan demikian konsumen dapat mengetahui kandungan gizi dan kelayakan makanan kemasan tersebut (Almatsier, 2011). Peraturan tersebut dibuat untuk melindungi konsumen dari bahaya keracunan. Keamanan pangan merupakan suatu hal yang harus diperhatikan karena dapat berdampak pada kesehatan, baik bagi anak-anak maupun orang dewasa. Penelitian yang dilakukan oleh Paratmanitya dan Aprilia (2016: 55) menunjukkan bahwa persentase makanan jajanan anak sekolah dasar yang mengandung boraks, formalin dan rhodamin-B masih cukup tinggi. Sehingga perlu pengawasan lebih lanjut dari pihak yang berwenang kepada para produsen makanan jajanan, terutama jenis bakso, sosis dan jeli yang paling sering ditemukan mengandung bahan kimia berbahaya.

Sementara kebiasaan membaca informasi nilai gizi pada produk makanan ataupun minuman kemasan belum membudaya di masyarakat. Padahal, hal ini sangat penting guna mengetahui nutrisi yang terdapat dalam produk tersebut. Manfaat lain dan membiasakan diri membaca informasi nilai gizi pada makanan ataupun minuman kemasan, yaitu untuk dapat membatasi asupan gula, garam, dan lemak per hari. Dengan demikian, setidaknya kita tidak berlebihan dalam mengonsumsi pangan tersebut yang bisa berakibat kenaikan berat badan atau memicu konsumsi gula ataupun garam berlebih.(Koran Sindo, 2016:29) Berita tersebut diperkuat oleh hasil penelitian Devi dkk (2013: 11) yang menyebutkan jumlah responden yang melakukan kesalahan praktek pemilihan makanan kemasan adalah 51,5\% sedikit lebih 90 besar dibandingkan dengan yang benar, yaitu $48,5 \%$. Penelitian tersebut juga mengungkapkan bahwa ada hubungan positif yang kuat antara tingkat pengetahuan responden tentang label makanan kemasan dengan praktek pemilihan makanan kemasan. Sehingga peneliti memberikan saran akan pentingnya sosialisasi dan pendidikan kepada masyarakat khususnya kelompok remaja tentang pentingnya menggunakan label produk makanan kemasan dalam pemilihan produk makanan dengan materi informasi nilai gizi.

Martalia (2003: 53) mengatakan bahwa pembelajaran matematika di setiap tingkat satuan pendidikan diharapkan mampu membekali peserta didik dengan keterampilan dan kemampuan menghadapi berbagai permasalahan matematika maupun kehidupan sehari-hari. Lange (1992) dalam Sugiman (2008: 64) memandang bahwa pembelajaran matematika yang baik adalah yang memperhatikan pada tiga dimensi tujuan, yakni dimensi menjadikan warga yang cerdas melalui literasi matematis, dimensi penyiapan ke dunia kerja dan ke sekolah lanjutan, dan dimensi matematika sebagai suatu disiplin. Pandangan ini sejalan dengan NCTM (2014) dalam Murtiyasa (2015: 39) yang menyebutkan bahwa kelemahan pembelajaran matematika saat inipara siswa tidak dapat menghubungkan konsep-konsep matematika di sekolah dengan pengalaman mereka sehari-hari. Pembelajaran matematika terlalu formal, kurang mengkaitkan dengan makna, pemahaman, dan aplikasi dari konsep konsep matematika, serta gagal dalam memberikan perhatian yang cukup terhadap kemampuan penalaran dan pemecahan masalah. Tak heran sehingga pada akhir penelitiannya Sugiman (2008:70)mengambil kesimpulan bahwa pandangan matematika sebagai aktivitas insani rupanya merupakan pilihan yang tepat dalam kerangka menjadikan warga negara Indonesia menjadi literasi dalam matematika.

Berdasarkan latar belakang diatas, peneliti akan membahas inovasi pembelajaran matematika guna menumbuhkan kemampuan 
literasi matematika berbasis kontek. Penelitian ini akan mengkhususkan kontek matematika dalam memilih makanan sehat dan bergizi pada makanan kemasan yang banyak dijual di sekolah atau super market. Dengan inovasi pembelajaran ini diharapkan siswa mampu memilih mana makanan yang layak dikonsumsi dan makanan yang tidak layak dikonsumsi dengan kemampuan matematika yang dimilikinya. Dengan penelitian pula diharapkan para guru bisa terinspirasi untuk melakukan inovasi pembelajaran matematika yang menyenangkan dan mudah diterima.

\section{Metode Penelitian}

Metode yang digunakan dalam penelitian ini adalah penelitian studi kepustakaan (library research). Dalam penelitian ini akan dikaji pengetahuan, gagasan, atau temuan yang terdapat didalam berbagai literatur sehingga memberikan informasi teoritis dan ilmiah terkait peningkatan kemampuan berpikir kritis siswa dalam memilih makanan sehat melalui pembelajran matematika berbasis konteks. Datadata yang dikumpulkan dan dianalisis merupakan data sekunder yang merupakan hasilhasil penelitian seperti buku-buku ilmiah, jurnal ilmiah, prosiding seminar nasional, laporan penelitian, situs internet dan sumber-sumber ilmiah lainya yang relevan dengan penelitian.

\section{Pembahasan}

\section{Kajian Pustaka}

Dalam kehidupan sehari-hari, siswa berhadapan dengan masalah yang berkaitan dengan personal, bermasyarakat, pekerjaan, dan ilmiah. Banyak diantara masalah tersebut yang berkaitan dengan penerapan matematika. Penguasaan matematika yang baik dapat membantu siswa menyelesaikan masalah tersebut. Pertanyaannya adalah kemampuan matematika yang seperti apa yang dibutuhkan untuk menyelesaikan masalah dalam kehidupan sehari-hari. Atau secara spesifik, kompetensi matematika apa untuk anak umur 15 tahun (yang diperoleh melalui sekolah atau latihan khusus) sehingga berguna untuk karir mereka kelak atau untuk melanjutkan pendidikan ke jenjang perguruan tinggi. Oleh karena itu dibutuhkan literasi matematika yang menjadi sasaran dari PISA.(Johar, 2012:32)

Literasi matematika menurut Sari (2015:719) adalah kemampuan mengunakan pengetahuan matematika guna memecahkan masalah sehari-hari secara lebih baik dan efektif. Literasi matematis dapat membantu individu untuk mengenal peran matematika di dunia nyata dan sebagai dasar pertimbangan dan penentuan keputusan yang dibutuhkan oleh masyarakat (OECD, 2010: 4). Selanjutnya OECD dalam Murtiyasa (2015:39) menyebutkan bahwa konsep tentang literasi matematika merupakan kemampuan individu untuk memformulasikan, menggunakan, dan menginterpretasikan matematika dalam berbagai konteks.Hal ini termasuk penalaran matematis dan menggunakan konsep-konsep matematika, prosedur, fakta, dan peralatan untuk menggambarkan, menjelaskan, dan memprediksi phenomena atau peristiwa.

Lange (2003: 77), menyatakan bahwa literasi matematika ditandai oleh beberapa kompetensi utama, yaitu ;

1. Berpikir dan bernalar matematika, yaitu meliputi kemampuan mengajukan pertanyaan berciri matematika; mengetahui sejumlah jawaban yang bisa ditawarkan oleh matematika; memahami keluasan maupun keterbatasan konsep matematika serta mampu menyiasatinya.

2. Berargumen matematika, yaitu mengetahui apa yang dimaksud dengan bukti; mengetahui perbedaan antara bukti dan penalaran matematika lainnya; mampu mengikuti dan menilai urutan dalam gagasan; mampu membuat dan mengetahui gagasan matematika.

3. Komunikasi matematika, yaitu mampu menyatakan gagasan dalam berbagai bentuk baik lisan, tulisan dan bentuk visual lainnya; memahami hasil pekerjaan orang lain.

4. Pemodelan, yaitu kemampuan menerjemahkan realitas ke dalam bentuk matematika; sebaiknya, menafsirkan model matematika dalam konteks atau realitasnya; bekerja dengan model; menguji (memvalidasi) model; memberi saran-saran 


\section{JURNAL GANTANG. September 2017; II(2): 89 - 97 \\ p-ISSN. 2503-0671 \\ e-ISSN. 2548-5547}

terhadap model atau penyelesaian matematika.

5. Mengajukan dan memecahkan masalah, meliputi kemampuan mengajukan, merumuskan, mendefinisikan, dan menyelesaikan masalah dengan berbagai cara.

6. Representasi, yaitu kemampuan menerjemahkan, membedakan, dan menafsirkan bentuk-bentuk representasi matematika dan objek atau situasi, serta memhami hubungan diantara representasi yang berbeda.

7. Simbol, yaitu mampu menggunakan operasi simbolik, formal, dan bahasa teknik.

8. Alat dan teknologi, yaitu kemampuan menggunakan alat bantu, termasuk teknologi apabila diperlukan.

Menurut Thomson et al. (2013:7), Kerangka PISA untuk literasi matematika disusun menjadi tiga komponen luas: Situasi dan konteks di mana masalah berada dan digunakan sebagai sumber stimulus; Konteks matematika dengan berbagai masalah dan pertanyaan yang berhubungan, dan yang diatur oleh gagasan menyeluruh tertentu; Dan kompetensi matematis yang harus ada diaktifkan untuk menghubungkan dunia nyata (di mana masalah dihasilkan) dengan matematika, dan kemudian Digunakan untuk memecahkan masalah. Aspek penting dari literasi matematika adalah keterlibatan siswa dalam menggunakan matematika pada berbagai situasi. Siswa diperlihatkan materi tertulis atau permasalahan dalam berbagai situasi yang dapat dipikirkan siswa, kemudian mereka mendaftar pengetahuan matematika yang dimilikinya untuk menganalisis dan menghadapi masalah tersebut.

Kerangka PISA membagi konten matematika dalam empat domain pengetahuan Thomson (2013: 7) yaitu

1. Ruang dan bentuk yang mengacu pada kurikulum geometri. Mencari kesamaan Dan perbedaan, mengenali bentuk dalam representasi yang berbeda dan dimensi yang berbeda, Memahami sifat benda dan posisi relatifnya, dan hubungannya antara representasi visual (keduanya dua dan tiga dimensi) dan benda nyata.

2. Perubahan dan hubungan yang berhubungan paling dekat dengan bidang kurikulum aljabar. mengetahui hubungan antara variabel dan pemikiran tentang hubungan dalam berbagai bentuk termasuk simbolis, aljabar, grafis, tabular dan geometris.

3. Kuantitas yaitu pemahaman tentang ukuran relatif, pengenalan pola numerik, dan penggunaan angka untuk mewakili jumlah dan atribut terukur dari objek dunia nyata (penghitungan dan ukur).

4. Ketidakpastian pemecahan masalah yang berkaitan dengan data dan kebetulan, yang umumnya sesuai dengan statistik dan probabilitas dalam kurikulum sekolah.

Menurut Thomson et al. (2013: 7) dalam Jufri (2015: 56), Komponen proses literasi matematika dalam PISA dikelompokkan menjadi tiga komponen yaitu:

a. Komponen proses reproduksi (reproduction cluster), siswa diminta untuk mengulang atau menyalin informasi yang diperoleh sebelumnya. Dari segi keterampilan, siswa dapat mengerjakan perhitungan sederhana yang mungkin membutuhkan penyelesaian tidak terlalu rumit dan umum dilakukan.

b. Komponen proses koneksi (connections cluster), dalam koneksi ini siswa diminta untuk dapat membuat keterkaitan antara beberapa gagasan dalam matematika, membuat hubungan antara materi ajar yang dipelajari dengan kehidupan dunia nyata di sekolah dan masyarakat. Dalam komponen ini pula siswa dapat memecahkan masalah yang sederhana. Khususnya siswa dapat memecahkan soal yang berkaitan dengan pemecahan masalah dalam kehidupan tetapi masih sederhana. Dengan demikian, siswa diharapkan dapat terlibat langsung dalam pengambilan keputusan secara matematika dengan menggunakan penalaran matematika sederhana.

c. Komponen proses refleksi (reflection cluster), komponen refleksi ini adalah 
kompetensi yang paling tinggi yang diukur kemampuannya dalam PISA yaitu kemampuan bernalar dengan menggunakan konsep matematika. Melalui uji kompetensi ini, diharapkan siswa berhadapan dengan suatu keadaan tertentu. Mereka dapat menggunakan pemikiran matematikanya secara mendalam dan menggunakannya untuk memecahkan masalah. Dalam melakukan refleksi ini, siswa melakukan analisis terhadap situasi yang dihadapinya, mengidentifikasi dan menemukan 'matematika' dibalik situasi tersebut.

Menurut Mahdiansyah dan Rahmawati (2014), Konteks dalam asesmen literasi adalah hal yang penting, sebab konteks membawa pola pikir siswa untuk mengingat ulang konsepkonsep yang telah dipelajarinya, menghubungkan dengan permasalahan yang ada dalam konteks, kemudian memformulasikan suatu solusi yang sesuai dengan konteks yang diberikan. Oleh karena itu, konteks dalam suatu asesmen berpengaruh terhadap hasil asesmen. Stacey (2011) dalam Mahdiansyah dan Rahmawati (2014), menekankan pentingnya konteks dalam pembelajaran dan asesmen, karena siswa dipersiapkan untuk menyambut tantangan masa mendatang, sehingga perlu dikenalkan dengan berbagai konteks yang mencakup berbagai aspek dalam kehidupannya. Mengingat pentingnya literasi dalam konteks menentukan mutu sumber daya manusia untuk modal memajukan bangsa, dan belum tersedianya kajian literasi yang konteksnya Indonesia, maka perlu dikaji pencapaian literasi siswa Indonesia di jenjang pendidikan menengah.

Sari (2015: 719) menyatakan bahwa terdapat banyak metode ataupun pendekatan pembelajaran yang dapat menfasilitasi pengalaman ini. Beberapa diantaranya adalah pendekatan Realistik matematika, problem based learning, problem solving, dan contextual teaching learning. Pada pendekatan pembelajaran yang disebutkan tersebut siswa akan dihadapkan pada masalah kontekstual atau masalah nyata yang akan membantu mereka mengkonstruksi pengetahuannya. Pada tahapan ini siswa akan mengunakan kemampuan literasinya untuk merumuskan masalah nyata kedalam masalah matematika, kemudian memecahkannya dan menafsirkannya dalam konteks nyata. Dengan cara ini mereka mengunakan kemampuan literasi matematikanya sekaligus mengembangkannya. Masalah yang digunakan dalam pembelajaran juga bukanlah sembarang masalah. Masalah yang digunakan sebaiknya memenuhi keempat karakteristik berikut: nyata, rumit, menarik dan kuat. Nyata yang dimaksudkan adalah masalah tersebut mengambarkan konteks umum dan masalah yang sebenarnya. Selain itu, masalah juga sebaiknya rumit sehingga menuntut siswa untuk mengidentifikasi pertanyaan yang tepat. Tidak hanya itu, masalah yang disajikan hendaknya tidak sekedar soal cerita biasa. Masalah yang disajikan dapat berupa masalah yang memiliki informasi berlebih ataupun ada yang belum diketahui.

Menurut Kadir (2013: 36), pembelajaran kontekstual merupakan salah satu alternatif pembelajaran yang dapat mengurangi verbalisme dan teoritis. Di samping itu, pembelajaran ini dapat memberikan penguatan pemahaman secara komprehensif melalui penghubungan makna atau maksud dari ilmu pengetahuan yang dipelajari siswa dengan pengalaman langsung dalam kehidupan yang nyata. Melalui model pembelajaran kontekstual, pengalaman belajar bukan hanya terjadi dan dimiliki ketika seseorang siswa berada di dalam kelas, tetapi jauh lebih penting dari itu adalah bagaimana membawa pengalaman belajar tersebut keluar dari kelas, yaitu pada saat ia dituntut untuk menanggapi dan memecahkan permasalahan yang nyata yang dihadapi sehari-hari. Sehingga pembelajaran kontekstual ini idealnya mengkaitkan permasalahan pada dunia nyata kepada teori yang akan dipelajarkan atau disajikan pada siswa, dan siswa secara aktif memecahkan permasalahan tersebut sesuai apa yang ia dapatkan melalui pengalaman dan dihubungkan dengan teori yang ia pelajari di sekolah oleh gurunya.

Sementara menurut Hasnawati (2006:

53), pembelajaran kontekstual (Contextual 


\section{JURNAL GANTANG. September 2017; II(2): 89 - 97 \\ p-ISSN. 2503-0671 \\ e-ISSN. 2548-5547}

Teaching and Learning) merupakan konsep belajar yang membantu guru mengaitkan antara materi yang diajarkan dengan situasi dunia nyata siswa dan mendorong siswa membuat hubungan antara pengetahuan yang dimilikinya dengan penerapannya dalam kehidupan mereka sebagai anggota keluarga dan masyarakat. Model pembelajaran kontekstual tidak bersifat ekslusif akan tetapi dapat digabung dengan model-model pembalajaran yang lain, misalnya: penemuan, keterampilan proses, eksperimen, demonstrasi, diskusi, dan lain-lain.

Hasibuan (2014: 11) menyatakan model pembelajaran contextual teaching learning (CTL), dapat membantu meningkatkan hasil belajar siswa karena model pembelajaran CTL ini lebih memfokuskan pada pemahaman serta menekankan pada pengembangan minat dan pengalaman siswa dalam kehidupan sehari-hari, bukan hanya sekedar hafalan sehari-hari. Sehingga dengan pembelajaran CTL ini siswa diharapkan dapat berfikir kritis dan terampil dalam memproses pengetahuan agar dapat menemukan dan menciptakan sesuatu yang bermanfaat bagi dirinya sendiri dan orang lain. Penelitian firdaus et al. (2017: 218) menunjukkan bahwa pembelajaran berbasis masalah mampu meningkatkan kemampuan literasi matematika dibanding dengan pembelajaran secara langsung.

\section{Memilih Makanan Sehat Dengan Pembelajaran Literasi Matematika}

Makanan yang sehat dan bergizi sangat penting untuk setiap orang, khususnya bagi anak-anak. Makanan yang sehat adalah makanan yang terjamin kebersihannya, bebas dari bahan pengawet, dan bahan kimia yang berbahaya lainnya. Sedangkan makanan yang bergizi berarti makanan yang bisa memenuhi standar kebutuhan gizi yang dibutuhkan untuk pertumbuhan, dan perkembangan tubuh seseorang. Makanan sehat dan bergizi akan menjauhkan tubuh dari penyakit karena bisa membantu pembentukan antibodi dan kekebalan yang lebih baik terhadap virus, bakteri, dan berbagai kuman penyakit. Kebiasaan jajan anak sekolah di Yogyakarta cenderung meningkat dan anak memilih konsumsi jajan yang kurang sehat. Kebiasaan jajan cenderung menjadi bagian budaya dari satu keluarga. Makanan jajanan di luar lingkungan sekolah seringkali tidak memperhatikan mutu gizi, kebersihan, dan keamanan bahan pangan. Tidak sedikit masalah yang timbul akibat orang tua kurang peduli terhadap makanan yang dikonsumsi anak di sekolah. Makanan yang tidak aman dan tidak bergizi menimbulkan penyakit, seperti diare bahkan kanker dan dapat mengakibatkan tidak tercapainya angka kecukupan gizi. (Noviani et al., 2016: 97)

Jika Anak membeli makanan atau minuman dalam kemasan sebaiknya langkah pertama yang harus diperhatikan adalah anak mampu membaca tanggal kadaluarsa yang tertera pada label kemasan. Selain memperhatikan tanggal kadaluarsa dalam membeli makanan kemasan juga harus memperhatikan kandungan nutrisi yang ada pada produk tersebut. Jadi kita bisa menikmati jajanan kemasan tanpa khawatir menimbulkan efek samping bagi kesehatan tubuh. Untuk mengetahui tanggal kadaluarsa dan nilai kandungan gizi, anak bisa meneliti dulu tanggal kadaluarsa dan kandungan gizi dari label yang tertera kemasan luar. Apakah tanggal kadaluarsa produk tersebut sudah mendekati atau sudah melampui? Apakah kandungan gizinya mencukupi kebutuhan tubuh kita? Dalam penelitian ini akan dibahas bagaimana menumbuhkan kemampuan berpikir kritis dalam memilih makanan kemasan yang sehat dengan pembelajaran literasi matematika berbasis kontek. Adapun konteks yang diambil ada dua yaitu tanggal kadaluarsa dan tabel nutrisi.

\section{a. Membaca Tanggal Kadaluarsa Produk \\ Kemasaan \\ Informasi umur simpan produk sangat} penting bagi banyak pihak, baik produsen, konsumen, penjual, dan distributor. Bagi Konsumen informasi umur simpan produk tidak hanya dapat mengetahui tingkat keamanan dan kelayakan produk untuk dikonsumsi, tetapi juga dapat memberikan petunjuk terjadinya 
perubahan citarasa, penampakan dan kandungan gizi produk tersebut. Menurut $\mathrm{H}$. Harris dan M. Fadli (2014:53), Umur simpan (shelf life) produk pangan merupakan salah satu informasi yang sangat penting bagi konsumen. Pencantuman informasi umur simpan menjadi sangat penting karena terkait dengan keamanan produk pangan dan untuk memberikan jaminan mutu pada saat produk sampai ke tangan konsumen. Menurut Institute of Food Science and Technology (1974) dalam Herawati (2008:124), umur simpan produk pangan adalah selang waktu antara saat produksi hingga konsumsi di mana produk berada dalam kondisi yang memuaskan berdasarkan karakteristik penampakan, rasa, aroma, tekstur, dan nilai gizi.

Metode pembelajaran literasi matematika untuk menentukan makanan kemasan yang layak dikonsumsi atau tidak bisa dimasukkan dalam pembelajaran matematika tematik di Sekolah Dasar, khususnya pada pembelajaran konsep bilangan. Pertama, guru menjelaskan kepada siswa tentang informasi apa saja yang terdapat dalam suatu produk kemasan. Kemudian guru menjelaskan apa kegunaan tanggal kadaluarsa dan bagaimana cara membaca tanggal kadaluarsa. Contoh misal dalam suatu kemasan tertera "baik digunakan sebelum 10122017" selanjutnya siswa diminta mengartikan tulisan tersebut. Guru bisa membantu dengan tabel bantu analisis kelayakan produk kemasan seperti tertera pada tabel.1 dibawah ini, untuk membantu siswa dalam membuat keputusan.

Tabel 1. Membaca Tanggal Kadaluarsa

\begin{tabular}{|c|c|c|}
\hline $\begin{array}{c}\text { Sebelum } \\
\text { tanggal } \\
\text { kadaluarsa }\end{array}$ & \multirow{4}{*}{$\begin{array}{c}\text { Tanggal } \\
\text { Kadaluarsa }\end{array}$} & $\begin{array}{c}\text { Sesudah } \\
\text { tanggal } \\
\text { kadaluarsa }\end{array}$ \\
\cline { 1 - 1 } $\begin{array}{c}\text { Layak } \\
\text { dikonsumsi }\end{array}$ & & $\begin{array}{c}\text { Tidak layak } \\
\text { dikonsumsi }\end{array}$ \\
\hline
\end{tabular}

Selanjutnya, siswa diminta mencari produk di supermarket kemudian siswa diminta untuk menganalisis produk tersebut secara berkelompok. Selanjutnya siswa diminta presentasi didepan kelas kapan produk tersebut diproduksi, kapan layak dikonsumsi, kapan tanggal kadaluarsa, dan kapan tidak layak untuk dikonsumsi. Contoh, suatu produk makanan tertulis dikemasannya tanggal kadaluarsa adalah 31 Agustus 2017. Tentukan apakah produk tersebut layak digunakan atau tidak!

Tabel 2. Evaluasi Produk Kemasan

\begin{tabular}{|c|c|c|}
\hline \multirow[b]{2}{*}{$\begin{array}{c}\text { Tanggal } \\
\text { kadaluarsa } \\
\text { (31 Agustus 2017) }\end{array}$} & \multicolumn{2}{|c|}{ Keputusan } \\
\hline & $\begin{array}{c}\text { Layak } \\
\text { Konsumsi }\end{array}$ & $\begin{array}{c}\text { Tidak } \\
\text { Layak } \\
\text { Konsumsi }\end{array}$ \\
\hline 2 September 2017 & & $\checkmark$ \\
\hline 01 Januari 2017 & $\checkmark$ & \\
\hline 12 Februari 2017 & $\checkmark$ & \\
\hline 17 desember 2017 & & $\checkmark$ \\
\hline 01 Agustus 2017 & $\checkmark$ & \\
\hline 03 April 2017 & $\checkmark$ & \\
\hline
\end{tabular}

b. Membaca Informasi Nilai Gizi

Informasi nilai gizi diharapkan dapat dimanfaatkan konsumen dalam melakukan pemilihan yang bijak terhadap produk pangan, terutama yang berkenaan dengan kandungan zat gizi di dalamnya sesuai dengan kebutuhannya. Pada saat yang sama pihak produsen berkesempatan untuk menyampaikan informasi zat gizi yang terkandung dalam produknya yang kemungkinan merupakan keunggulan produk tersebut dibanding produk lainnya sesuai dengan cara pencantuman yang ditetapkan.

Upaya menumbuhkan kemampuan berpikir kritis untuk memilih makanan sehat dapat dilakukan dengan kegiatan praktek lapangan. Namun sebelum siswa terjun ke lapangan, seyogyanya guru menjelaskan kepada siswa tentang informasi nilai gizi yang terletak pada produk makanan kemasan. Setelah siswa memahami informasi nilai gizi yang terletak pada produk makanan kemasan. Untuk memudahkan pemahaman siswa guru bisa membuat alat peraga. Selanjutnya siswa diminta untuk mencari dua produk yang sejenis, kemudian siswa diminta untuk mendata kandungan gizi dari kedua produk tersebut, selanjutnya siswa diminta untuk membandingkan kandungan gizi dari kedua tabel tersebut dan membuat kesimpulan dari kegiatan tersebut secara berkelompok. Kegiatan yang terakhir 
adalah siswa mempresentasikan hasil penelitiannya kemudian guru memberikan masukan dan umpan balik dari hasil presentasi siswa. Berikut ini contoh tabel kandungan gizi yang dapat dibuat guru:

Tabel 3. Evaluasi informasi Kandungan Gizi

\begin{tabular}{|c|c|c|c|}
\hline $\begin{array}{c}\text { Informasi } \\
\text { Gizi }\end{array}$ & $\begin{array}{c}\text { Produk } \\
\text { A }\end{array}$ & $\begin{array}{c}\text { Produk } \\
\text { B }\end{array}$ & Ket \\
\hline $\begin{array}{l}\text { Total } \\
\text { Energi }\end{array}$ & 1500 & 1400 & $\begin{array}{c}\text { Total energi } \\
\text { Produk A } \\
\text { Total energi } \\
\text { produk B }\end{array}$ \\
\hline Lemak & 500 & 300 & $\begin{array}{c}\text { Lemak produk } \\
\text { A > Lemak } \\
\text { produk B }\end{array}$ \\
\hline Protein & 200 & 400 & $\begin{array}{c}\text { Protein } \\
\text { produk }<\text { A } \\
\text { Protein } \\
\text { produk B }\end{array}$ \\
\hline Karbohitrat & 400 & 300 & $\begin{array}{c}\text { Karbohitrat } \\
\text { produk A > } \\
\text { Karbohitrat } \\
\text { produk B }\end{array}$ \\
\hline Natrium & 75 & 30 & $\begin{array}{c}\text { Natrium } \\
\text { produk A > } \\
\text { Natrium } \\
\text { produk B }\end{array}$ \\
\hline Kalium & 70 & 75 & $\begin{array}{c}\text { Kalium } \\
\text { produk } \mathrm{A}< \\
\text { kalium produk } \\
\text { B }\end{array}$ \\
\hline Kalsium & 75 & 75 & $\begin{array}{c}\text { Kalsium } \\
\text { produk A = } \\
\text { Kalsium } \\
\text { produk B }\end{array}$ \\
\hline Vitamin A & 30 & 100 & $\begin{array}{c}\text { Vitamin A } \\
\text { produk A } \\
<\text { Vitamin A } \\
\text { produk B }\end{array}$ \\
\hline Vitamin C & 75 & 60 & $\begin{array}{c}\text { Vitamin C } \\
\text { produk A > } \\
\text { Vitamin C } \\
\text { produk B }\end{array}$ \\
\hline Mineral & 75 & 60 & $\begin{array}{c}\text { Mineral } \\
\text { produk A > } \\
\text { Mineral } \\
\text { produk B }\end{array}$ \\
\hline
\end{tabular}

Dua kegiatan penelitian ini sangat cocok diterapkan pada pembelajaran matematika di sekolah dasar dengan tema tematik, dengan demikian siswa akan memahami bahwa matematika merupakan pembelajaran yang menyenangkan dan erat kaitanya dengan kehidupan manusia.

\section{Penutup}

Menumbuhkan kemampuan berpikir kritis dalam memilih makanan sehat khususnya pada makanan kemasan pada pembelajaran literasi matematika berbasis konteks, dapat dilakukan pada pembelajaran tematik di sekolah dasar khususnya pada sub pokok pembahasan perbandingan. Literasi matematika merupakan kemampuan mengunakan pengetahuan matematika guna memecahkan masalah seharihari secara lebih baik dan efektif. Adapun proses pembelajaran dimulai dengan beberapa tahap. Pertama, guru membimbing siswa untuk meneliti tanggal kadaluarsa dan informasi nilai gizi dalam produk kemasan tersebut. Kedua, siswa untuk melakukan penelitian terhadap beberapa produk kemasan yang beredar di pasaran seperti supermarket atau toko di sekitar sekolah secara berkelompok dengan focus penelitian tanggal kadaluarsa dan informasi nilai gizi. Ketiga, siswa mempresentasikan hasil penelitian di depan kelas. Keempat guru memberikan umpan balik berupa penilaian dan saran dari hasil penelitian siswa. Dengan adanya penelitian ini, peneliti berharap tumbuhnya inovasi pembelajaran dalam bidang matematika yang mampu meningkatkan motivasi siswa dalam belajar matematika dan menerapkan matematika dalam segala bidang kehidupan.

\section{Daftar Pustaka}

Almatsier, Sunita. (2011). Gizi Seimbang Dalam Daur Kehidupan. Jakarta: Gramedia Pustaka Utama.

Ardiyaningrum, M. (2013). Upaya peningkatan kemampuan pemecahan masalah matematis siswa kelas VII SMP Muhammadiyah 9 Yogyakarta melalui penerapan pendekatan pembelajaran 
problem posing, Literasi Jurnal Ilmu Pendidikan 4(1): 53.

Devi, V. C., A. Sartono, dan J. T. Isworo, (2013). Praktek Pemilihan Makanan Kemasan Berdasarkan Tingkat Pengetahuan Tentang Label Produk Makanan Kemasan, Jenis Kelamin, dan Usia Konsumen di Pasar Swalayan ADA Setiabudi Semarang. Jurnal Gizi Universitas Muhammadiyah Semarang 2(2): 11.

Firdaus, F. M., Wahyudin, dan T. Hermawan. (2017). Improving primary students' mathematical literacy through problem based learning and direct instruction. Academicjournals 12(4):218.

Harris, H. dan M. Fadli. (2014). Penentuan umur simpan (shelf life) pundangseluang (rasbora sp) yang dikemas menggunakankemasan vakum dan tanpa vakum, Jurnal Saintek Perikanan 9 (2): 53.

Hasibuan, I. (2014). Model pembelajaran CTL. Logaritma 2 (01):11.

Hasnawati. (2006). Pendekatan contextual teaching learning hubungannya dengan evaluasi pembelajaran, Jurnal Ekonomi \& Pendidikan 3 (1): 53.

Herawati. (2008). Penentuan Umur Simpan Pada Produk Pangan. Jurnal Litbang Pertanian 27(4): 124.

Johar, R. (2012). Domain Soal PISA untuk Literasi Matematika. Jurnal Peluang 1(1): 32 .

Jufri, L. H. (2015). Penerapan Double Loop Problem Solving untuk Meningkatkan Kemampuan Literasi Matematika Level 3 pada Siswa Kelas VIII SMPN 27 Bandung. LEMMA 2(1): 56

Kadir, A. (2013). Konsep pembelajaran kontekstualdi sekolah, Dinamika Ilmu 13( 3): 36.

Koran Sindo. (2016). Pentingnya Membaca Label Pangan. 17 Maret.Halaman 29. Jakarta.

Lange, J. D. (2003). Mathematics For Literacy. Quantitative Literacy: Why Numeracy Matters for Schools and Collage. The National Council on Education and the Disciplines. Princeton.

Mahdiansyah dan Rahmawati. (2014). Literasi Matematika Siswa Pendidikan Menengah: Analisis Menggunakan Desain Tes Internasional Dengan
Konteks Indonesia, Jurnal Pendidikan dan Kebudayaan 20 (4): 453

Murtiyasa, B. (2015). Tantangan Pembelajaran Matematika Era Global. Prosiding Seminar Nasional Matematika dan Pendidikan Matematika. UMS: 39,

Noviani, K., E. Afifah, dan D. Astiti. (2016). Kebiasaan jajan dan pola makan serta hubungannya dengan status gizi anak usia sekolah di SD Sonosewu Bantul Yogyakarta. Jurnal Gizi dan Dietetik Indonesia 4 (2): 98.

(OECD). 2010. PISA 2012 Matemathics Framework. PISA, OECD Publishing.Paris.

Paratmanitya, Y. dan V. Aprilia. (2016). Kandungan bahan tambahan pangan berbahaya pada makanan jajanan anak sekolah dasar di Kabupaten Bantul. Jurnal Gizi dan Dietetik Indonesia 4(1): 55.

Sari, R. H. N. (2015). Literasi matematika: Apa, Mengapa, dan Bagaimana? Prosiding Seminar Nasional Matematika dan Pendidikan Matematika. UNY:719.

Thomson, S., K. Hillman, dan L. D. Bortoli. (2013). A Teacher's Guide to PISA Mathematical Literacy.ACER Press. Australia.

Sugiman, (2008), Pandangan matematika sebagai aktivitas insani beserta dampak pembelajarannya, Jurnal pendidikan matematika 2(2): 64-70. 
JURNAL GANTANG. September 2017; II(2): 89 - 97

p-ISSN. 2503-0671

e-ISSN. 2548-5547 